\title{
Erratum to: Computerized transrectal ultrasound (C-TRUS) of the prostate: detection of cancer in patients with multiple negative systematic random biopsies
}

Tillmann Loch

Published online: 15 January 2012

(C) Springer-Verlag 2012

Erratum to: World J Urol (2007) 25:375-380

DOI 10.1007/s00345-007-0181-8

This article "Computerized transrectal ultrasound (C-TRUS) of the prostate: detection of cancer in patients with multiple negative systematic random biopsies" published in World Journal of Urology (2007) 25:375-380 is a translation of the article "Computergestützter transrektaler Ultraschall (C-TRUS) in der Diagnostik des Prostatakarzinoms" published in the journal "Der Urologe" [A] (2004) 43:1377-1384.

The online version of the original article can be found under doi:10.1007/s00345-007-0181-8.

T. Loch $(\square)$

Klinik für Urologie des Diakonissenkrankenhaus Flensburg,

Lehrkrankenhaus der Christian-Albrechts-Universität Kiel des,

Universitätsklinikums Schleswig-Holstein,

Marienhoelzungsweg 2, 24939 Flensburg, Germany

e-mail: lochti@diako.de 